\title{
MACHADO DE ASSIS, JOAQUIM NABUCO, EÇA DE QUEIRÓS E A IMIGRAÇÃO CHINESA - QUAL MEDO?
}

\section{MACHADO DE ASSIS, JOAQUIM NABUCO, EÇA DE QUEIROS AND THE CHINESE IMMIGRATION - WHICH FEAR?}

Osmar Pereira Oliva*

RESUMO: Este artigo analisa crônicas de Machado de Assis, publicadas no Jornal Gazeta de Notícias, dois discursos parlamentares de Joaquim Nabuco e um artigo de Eça de Queirós sobre a imigração chinesa e japonesa como forma de substituir o trabalho dos negros escravos.

PALAVRAS-CHAVE: negro, escravidão, imigração.

ABSTRACT: This article analyses chronicles of Machado de Assis, published in the newspaper Gazeta de Notícias, two parliamentary speeches of Joaquim Nabuco and an article of Eça de Queirós about the Chinese and Japanese immigration like the form of substituting the work of the black slaves.

KEY WORDS: black man, slavery, immigration

* Professor titular de Literaturas de Língua Portuguesa na Universidade Estadual de Montes Claros - Unimontes. Pesquisador do CNPq e da FAPEMIG. 



\section{MACHADO DE ASSIS, JOAQUIM NABUCO, EÇA DE QUEIRÓS E A IMIGRAÇÃO CHINESA - QUAL MEDO?}

Mas virá, todavia, o homem amarelo! Virá muito humildemente, muito pacificamente, em grandes paquetes, com a sua trouxa às costas. Virá, não para assolar, mas para trabalhar. E é essa a invasão perigosa para o nosso velho mundo, a invasão surda e formigueira do trabalhador chinês. ${ }^{1}$

Este texto é resultado de uma pesquisa mais ampla que venho desenvolvendo há alguns anos sobre dois grandes escritores de língua portuguesa do século XIX: Eça de Queirós e Machado de Assis. É bem conhecida a crítica literária do escritor brasileiro a $O$ Primo Basílio e a O crime do Padre Amaro, mas eu passei a investigar que aproximações poderiam ser feitas quanto ao estilo dos dois autores, à técnica de construção de suas narrativas, aos temas mais freqüentes em suas obras, à preferência de por determinados gêneros literários e à participação crítica em jornal e revistas da época. Indiscutivelmente, a ficção queirosiana difere da ficção machadiana do ponto de vista da estética naturalista e também por ser mais clara e objetiva a reflexão sobre a decadência da nação e o atraso econômico e intelectual na obra do autor de Os Maias. Outros aspectos, no entanto, são mais evidentes na ficção desses autores: a escrita em torno de pares masculinos, que produz um efeito homoerótico, as intertextualidades com a bíblia e as representações do Oriente, objeto de minha análise neste texto.

\footnotetext{
${ }^{1}$ QUEIRÓS, s/d., p. 1267.
} 
Ainda que sejam freqüentes na obra de Machado de Assis as temáticas orientais, privilegiarei aqui apenas a imigração chinesa do ponto de vista de dois ficcionistas colaboradores do jornal carioca "Gazeta de Notícias" e de um deputado. A tese do absenteísmo machadiano há muito foi desconstruída pelos estudos de Raimundo Magalhães Jr. E Brito Broca ${ }^{2}$. No entanto, alguns críticos analisaram a ficção desse autor como um meio de representar o que pensava Machado de Assis da sociedade do seu tempo, mas pouco se tem publicado sobre suas crônicas. Lúcia Miguel Pereira ${ }^{3}$, aponta a importância que teve Quintino Bocaiúva na vida de Machado de Assis, a partir do momento que deu a ele a oportunidade de colaborar como cronista no Jornal “Diário do Rio de Janeiro”, em 1860. Ainda que Machado de Assis tivesse apenas 21 anos de idade, não teve medo de opinar sobre os acontecimentos importantes de seu tempo nem a prudência dos iniciantes: "Os primeiros folhetins ainda são exitantes; logo, porém, se apruma. Em fins de 61 já o leitor o sente seguro de si, senhor do seu estilo e das suas


do ministro do Império José Ildefonso de Souza Ramos, e o conselheiro Pena, não poupando críticas à retórica parlamentar, aos atos do ministério e até aos discurso da coroa ${ }^{5}$. Segundo Miguel Pereira, Machado foi, até os 26 anos, "um jornalista destemido e agressivo, comentando sem rebuços

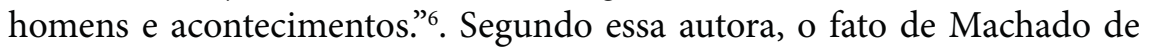
Assis ter assumido o cargo de chefe de seção da Secretaria de Agricultura, em 1884, não lhe permitirá opinar sobre assuntos em que estivesse interessado o governo: "No tempo da Gazeta, era a secretaria que o envolvia, e ele, salvaguardando o seu modo de ser íntimo, adotou uma prudência burocrática"?.

Mais adiante, outros equívocos surgem no estudo de Lúcia Miguel Pereira, ao afirmar que foi um traço característico e marcante do espírito

\footnotetext{
${ }^{2}$ A esse respeito, ver MAGALHÃES JR, Raimundo. Machado desconhecido. Rio de Janeiro: Civilização Brasileira, 1955; e BROCA, Brito. Machado de Assis e a política e outros estudos. São Paulo: Polis, 1983.

${ }^{3}$ MIGUEL PEREIRA, 1998, p. 72.

${ }^{4}$ MIGUEL PEREIRA, 1998, p. 77.

${ }^{5}$ Para outras informações sobre as críticas machadianas aos discursos parlamentares, ver BOSI, Alfredo. "O teatro político nas crônicas de Machado de Assis". In Brás Cubas em três versões - Estudos Machadianos. São Paulo: Companhia das Letras, 2006.

${ }^{6}$ MIGUEL PEREIRA, 1988, p. 81.

7 Idem, p. 83.
} 
de Machado de Assis a aversão não só à crença religiosa, como a qualquer espécie de mística ${ }^{8}$. O outro equívoco pauta-se na afirmação de que Machado teria ficado, senão indiferente, pelo menos frio quanto aos grandes movimentos de sua época: a Abolição da escravatura e a República. Lúcia Granja (2000) dedicou-se ao estudo das crônicas machadianas da década de 60, publicadas no "Diário do Rio de Janeiro" e discutiu as técnicas de construção da crônica, como o tom dialogal com o leitor e a poética das citações, que seriam incorporadas à ficção do autor de D. Casmurro, mas não perdeu de vista a análise das polêmicas e críticas que Machado criava em torno de políticos e acontecimentos históricos daquela época. A autora aponta que os estudos já realizados por Brito Broca, Roberto Schwarz, Raymundo Faoro e John Gledson ${ }^{9}$, demonstram que as opiniões dos narradores machadiano não estão sob a égide da neutralidade, pois expressam uma circunstância e uma visão históricas de períodos completos da histórica do Brasil.

\section{A transição do trabalho escravo para o trabalho livre}

Desde 1831, a Inglaterra aprovara uma lei abolindo o tráfico negreiro, mas o Brasil continuava contrabandeando africanos cativos até meados do século XIX, com a justificativa de que a economia brasileira dependia do trabalho escravo. Somente em 1850, convencidos da inevitabilidade da abolição, os fazendeiros das áreas cafeeiras tornaram-se interessados em promover a imigração para prover o trabalho desempenhado pelos negros ${ }^{10}$. Até 1870 ,

\footnotetext{
${ }^{8}$ A ficção machadiana contraria essa afirmação. Em Esaú e Jacó, representam-se as crenças espírita, católica e afro-religiosa; em "O alienista" e Quincas Borba, nota-se uma mística de cunho filosófico; em vários contos, percebem-se releituras bíblicas, como "Adão e Eva", "Na Arca", "A Igreja do diabo", "O sermão do diabo", o que acentua uma preocupação com a temática mística e, nas crônicas de "A Semana", é recorrente a temática do espiritismo como uma crença que o narrador criado por Machado de Assis confessa admirar e acreditar, quase como um duplo do próprio autor das crônicas.

9 Ver os estudos de SCHWARZ, Roberto. Um mestre na periferia do capitalismo: Machado de Assis. São Paulo: Duas Cidades, 1991; FAORO, Raymundo. Machado de Assis: a pirâmide e o trapézio. Rio de Janeiro: Globo, 1988; GLEDSON, John. Machado de Assis - ficção e história. São Paulo: Paz \& Terra, 2003.

${ }^{10}$ Há muitos estudos sobre a integração do negro na sociedade brasileira no período de transição do Império para a República - escravidão para a abolição - e raras exceções problematizam a marginalização do índio nesse processo. Vale ressaltar, no entanto, as opiniões de Nísia Floresta, referindo-se às mulheres brasileiras pobres, negras e índias, que constituiriam "numerosas e respeitosas legiões de bravos." In Opúsculo Humanitário. Rio de Janeiro: M. A. Silva Lima, 1853, citada por Célia Maria Marinho de Azevedo (2004, p. 49).
} 
houve tentativas de trazer imigrantes brancos do Sul dos Estados Unidos ou da Europa ${ }^{11}$ (italianos e alemães), mas, como havia dificuldades para esse fim, o Brasil passou a discutir a imigração asiática. Os fazendeiros e demais partidários da imigração chinesa argumentavam que o trabalho dos asiáticos no Brasil seria de caráter temporário, de transição, até que chegassem os imigrantes "ideais". Nesse sentido, Thomas E. Skidmore ${ }^{12}$, afirma que o cônsul-geral do Brasil em Nova York, Salvador de Mendonça, foi incubido de estudar a imigração chinesa nos Estados Unidos e se tornou partidário entusiasta desses imigrantes, os quais considerava trabalhadores inteligentes, frugais e industriosos. Segundo Célia Maria Marinho de Azevedo ${ }^{13}$, em 1879, o deputado Ulhoa Cintra apresentou um projeto determinando a aplicação de um fundo monetário considerável para a introdução de mil asiáticos em São Paulo. Estava iniciada a polêmica que apresentava uma dupla face: a imigração chinesa como um novo modelo de escravidão no Brasil e a conseqüente miscigenação do brasileiro com o oriental, tido como raça inferior e degradada. Aqui, pretendemos discutir o que pensavam três intelectuais de língua portuguesa que conviveram com esses problemas, Joaquim Nabuco, Machado de Assis e Eça de Queirós, por razões distintas ${ }^{14}$. Nabuco, por ser um abolicionista, que utiliza os seus discursos com o apa-

\footnotetext{
${ }^{11}$ Sobre os esforços de intelectuais e políticos brasileiros de apresentarem uma imagem positiva do Brasil no exterior, a fim de atrair imigrantes europeus, ver o excelente estudo de Thomas E. Skidmore (1989), sobretudo o capítulo 4, intitulado "A imagem nacional e a procura de imigrantes." Segundo esse autor, "Nos anos que se estendem do fim do Império a 1920, quase todos os brasileiros educados continuaram, ainda, a assumir que o Brasil podia, e, até, deveria receber imigrantes, especialmente da Europa. A fim de atraí-los, políticos e escritores tanto cuidaram de projetar uma imagem do país capaz de impressionar tanto europeus ocidentais quanto norte-americanos". (SKIDMORE, 1989, p. 145). Para tal fim, o Brasil participou de grandes mostras internacionais, como a Exposição de 1851, no Palácio de Cristal, em Londres; a Exposição de 1873, em Viena, e a Exposição de 1889, em Paris, entre outras.

${ }^{12}$ SKIDMORE, 1989, p. 41.

${ }^{13}$ AZEVEDO, 2004, p. 126.

${ }^{14} \mathrm{O}$ debate sobre a imigração chinesa também está presente em discursos de parlamentares, cartas e artigos, publicados nos jornais da época, como o posicionamento do deputado gaúcho Silveira Martins e do Visconde de Taunay, como aponta o professor José Luís Jobim em "Quem deve ser brasileiro? As opiniões de Taunay e Machado de Assis sobre a nacionalização". Segundo Jobim: "Efetivamente, não só Taunay era favorável à imigração de procedência européia, como era contra a de asiáticos." Para o autor de Inocência, os chineses de Cantão e Shangai eram gente má, miserável, que, se viesse para o Brasil, só poderia trazer vícios e nada mais. (In JOBIM, 2005, p. 15).
} 
rente fim de convencer os brasileiros a evitar uma nova escravização, mas que acaba revelando um terrível medo da raça amarela; Machado, por ser um mulato, e por ter escrito seis de suas crônicas publicadas no "Gazeta de Notícias” em que aparece o tema da imigração oriental e, por último, Eça, que também colaborava com esse jornal carioca, por ter sido cônsul em Havana e convivido de perto com a imigração dos chins para as Antilhas Cubanas e por ter publicado um artigo em que discute a guerra entre Japão e China pela posse da Coréia, mas discutindo nele, também, a questão da imigração chinesa, como veremos adiante.

\section{Joaquim Nabuco e o medo amarelo}

Em $1^{\circ}$ de setembro de 1879, Joaquim Nabuco, deputado pernambucano, pronuncia um discurso no qual reflete sobre a transição do trabalho escravo para o trabalho livre e deixa emergir a questão da imigração chinesa e a tese do branqueamento da raça, defendidas por Henry Thomas Buckle e Arthur de Gobineau. A influência da teoria eugênica foi tamanha que contagiou José do Patrocínio e André Rebouças, descendentes de mulatos, abolicionistas que tinham preconceitos raciais contra os negros. Mesmo que defendessem a liberdade definitiva dos negros, permanecia o problema racial, pois eles se identificavam com as teorias eugênicas que defendiam a supremacia da raça ariana sobre as demais. Assim, é perceptível nos documentos da época, o posicionamento favorável à miscigenação com o branco europeu, que "melhoraria" genética, moral e intelectualmente os mestiços brasileiros. Nas palavras iniciais do seu discurso, já se percebe o tom preconceituoso e racista de Joaquim Nabuco:

Não se trata simplesmente de travar relações com a China, de aproximar dois dos maiores impérios do mundo: trata-se de uma verdadeira emigração asiática para o Brasil, e essas relações diplomáticas que se quer abrir, não têm outro fim, não têm outro intuito senão mongolizar o nosso país. ${ }^{15}$

Ideologicamente envolvido com o liberalismo econômico, mas representante de uma oligarquia rural conservadora, Joaquim Nabuco argumenta que a China leva ao extremo o respeito das suas tradições e dos seus antepassados. É, portanto, uma nação velha, enquanto o Brasil toma a tangente

\footnotetext{
${ }^{15}$ NABUCO, 1950, p. 141.
} 
do futuro, da evolução. Por outro lado, o parlamentar se coloca como um europeu, ou um assimilado, ameaçado a desaparecer na presença da raça mongólica. Nota-se que a identidade brasileira é pensada do ponto de vista do branco, europeu ou europeizado, o índio sequer é mencionado em seus discursos, e o negro é pouco referido:

Na luta da existência, colocado o chim ao lado do branco ou do negro, colocado ao lado de todos os mestiços que possa haver no país, o chim forçosamente, por leis naturais que vou expor, acabará por tornar-se, dentro de um prazo de tempo que só nos restaria calcular, o senhor deste país, como ele espera ser o último habitante do mundo. ${ }^{16}$

Esse trecho revela bem o temor do pernambucano porque o chim poderia se estabelecer de vez no Brasil, juntar economia e aumentar aqui a população amarela. O seu medo é que a resistência dos chineses a quaisquer adversidades favorece a sua explosão demográfica, "contaminando" a raça brasileira. No entanto, na condição do abolicionista que era, Nabuco ameniza ou dissimula o seu racismo em relação ao oriental, com a argumentação de que se fossem melhoradas as condições de vida dos escravos libertos e seus descendentes, eles se fixariam nas terras onde nasceram e supririam a escassez da mão-de-obra para a lavoura, o que tornaria a imigração chinesa desnecessária.

Para reforçar a sua argumentação contra imigração chinesa, Nabuco cita exemplos de Cuba e Peru, onde os coolies eram praticamente escravos nas lavouras. Portanto, o Brasil não poderia transitar da escravidão negra para a escravidão amarela. No entanto, o medo do abolicionista não era de um novo modelo de cativeiro humano e, sim, da miscigenação e da mongolização da nossa população. Outro exemplo negativo da imigração chinesa é o da Califórnia, no início da década de 1850, onde o sistema de contratação dos chins era menos severo do que os de Cuba e do Peru. Lá, o chim, em constante privação, contentava-se com um salário diminutíssimo, respirava, dormia e habitava em verdadeiros focos de infecção; afastava a emigração, degradava o resto do país. Reforçando a resistência dos chineses às adversidades, Nabuco ainda informa:

${ }^{16}$ NABUCO, 1950, p. 142. 
Ainda há pouco estava eu lendo uma descrição de Pequim e vendo os pratos que os restaurantes daquela capital servem aos seus hóspedes; no sítio de Paris não houve desses jantares, em que as carnes de gato, de cão, de rato são as principais iguarias. Não há nada de que o chim não se alimente; ele aprendeu por uma longa experiência, como povo, a comer tudo, a tirar meios de subsistência de tudo. ${ }^{17}$

Com essas características, o chim pode fazer uma economia que nenhuma outra raça pode. O discurso é concluído com um tom nacionalista. O parlamentar, na condição de um estadista, afirma que não seria um brasileiro se não tivesse um pensamento para o futuro da pátria - caso fosse aceita a imigração chinesa, a nossa história seria marcada com uma cruz preta. Em 3 de setembro de 1879, um novo discurso é proferido em "resposta ao ministro de estrangeiros sobre a imigração chinesa”. A tônica do discurso é a mesma do primeiro e Nabuco resgata e resume o que afirmou no pronunciamento anterior. Acrescenta, no entanto, aquilo que vejo como a maior preocupação dele: o medo da mestiçagem amarela e da prosperidade dessa raça:

...os chins a princípio emigram como todos os homens, com desejo de voltar à pátria; mas atrás dos primeiros que vão, partem outros; transporta-se para 0 estrangeiro pouco a pouco uma parte da cidade, um torrão da pátria chinesa, com os hábitos, divertimentos, associações, com tudo o que eles tinham deixado; forma-se, como em S. Francisco, um bairro chinês, que faz lembrar HongKong ou Cantão, e por fim os que foram para voltar muitas vezes ficam. ${ }^{18}$

A grande preocupação do "estadista do futuro" não é com uma nova forma de escravidão no Brasil, mas, sim, com a permanência do chinês, que, acostumado a ganhar pouco, afastaria a mão-de-obra dos operários e impediria a entrada dos imigrantes "ideais", os italianos e alemães, que "branqueariam" a nossa raça. Com o estabelecimento do chim, haveria o inevitável cruzamento racial, "piorando" o brasileiro. No primeiro discurso, Joaquim Nabuco já advertia sobre os aspectos negativos da imigração chi-

\footnotetext{
${ }^{17}$ NABUCO, 1950, p. 160.

${ }^{18}$ NABUCO, 1950, p. 76-77.
} 
nesa. Numa postura preconceituosa e racista ${ }^{19}$, amparado no relatório da comissão paulista de lavradores de que fazia parte o ministro da imigração, o deputado afirma:

Chamo a atenção da casa para as palavras do nobre ministro de estrangeiros; elas mostram a que ponto pode chegar o amor pela importação dos coolies, porque a lavoura de S. Paulo mostra querê-la a despeito de toda evidência, que ela mesma confessa, dos funestos efeitos para o nosso país, moral, física, econômica, socialmente falando da imigração asiática. ${ }^{20}$

Convém assinalar que Nabuco estava proferindo um discurso contra a aprovação de crédito para a importação de chineses. Dessa forma, habilmente, ele utiliza palavras do relatório daqueles que tinham interesse nessa imigração para a combater. O parlamentar vale-se, portanto, da fala do outro como base para a sua argumentação. Nessa perspectiva, arremata a sua opinião:

O nobre ministro, por conseqüência, e a comissão do congresso agrícola mostravam que os chins não poderiam deixar de contaminar a nossa população, que o seu caráter subserviente e imoral havia por força de afastar imigrantes europeus, que eles haviam de imprimir à nossa civilização um movimento de regresso, de prolongar aqui o baixo nível moral que os caracteriza... ${ }^{21}$

Pelo que fica exposto, acreditamos que o medo de Joaquim Nabuco relacionava-se menos com a instituição de um novo modelo de escravização no Brasil e mais com o perigo de os brasileiros se mongolizarem e a nossa civilização, progressiva e ocidental, se tornasse uma civilização imóvel, antiga e asiática, segundo palavra do próprio parlamentar.

\footnotetext{
${ }^{19}$ Emília Viotti da Costa (1999) desenvolveu estudos interessantes sobre a transição do trabalho escravo para o trabalho livre e estabeleceu comparações entre os sistemas escravocratas no Brasil e nos Estados Unidos, desmitificando a imagem da democracia racial e do senhor benevolente, a partir das concepções de Gilberto Freyre (Casa Grande e Senzala; Região e Tradição). Para essa autora, a elite brasileira tinha uma atitude tolerante perante a miscigenação, e o proprietário de escravos brasileiro raramente se envergonhava de reconhecer seus descendentes mulatos e de garantir-lhes a alforria. Tese de que discordamos, como procuramos apontar neste trabalho.

${ }^{20}$ Idem, p. 147.

${ }^{21}$ NABUCO, 1950, p. 148. Grifos do original.
} 


\section{Eça de Queirós - chineses e japoneses}

Eça de Queirós publicou, de $1^{\circ}$ a 6 de dezembro de 1894, no Jornal "Gazeta de Notícias" do Rio de Janeiro, o artigo "Chineses e japoneses". No início do seu artigo, Eça descreve a visão estereotipada que europeus têm do asiático:

Mas esses povos da extrema Ásia, por ora só os conhecemos pelos traços exteriores e excessivos do seu exotismo. Com certos traços estranhos de figura e trajo, observados em gravuras, com detalhes de costumes e cerimônias, aprendidos nos jornais (artigo variedades) e sobretudo com o que vemos da sua arte, toda caricatural ou quimérica - é que nós formamos a nossa impressão concisa e definitiva da sociedade chinesa e japonesa. ${ }^{22}$

Desdobrando essa visão fantasiosa do oriental, segundo a concepção européia, Eça caracteriza o chinês como um ratão amarelo, de olhos oblíquos, de comprido rabicho, com unhas de três polegadas, que exala aroma de sândalo e de ópio; o japonês é um magricela de crânio rapado, com dois enormes sabres enfiados na cintura, jovial e airado, sempre ocioso, gastando as horas entre jardins de chá. Para tal efeito, retoricamente, o autor português utiliza o "nós" - pronome pessoal plural que dá idéia de pensamento coletivo ao que se expõe e, ao mesmo tempo, ironiza o seu próprio discurso, como se percebe no trecho citado acima e no seguinte: "O que dele, [Coréia - País Ermitão] na Europa, nós melhor conhecemos, por estampas (...)"23; Depois de demonstrar os equívocos dos europeus em relação ao que se diz conhecer dos orientais, Eça concluirá

Que por trás do rabicho e dos guarda-sóis de papel, e das caturrices, e de todo o exotismo, existam sólidas instituições sociais e domésticas, uma velha e copiosa literatura, uma intensa vida moral, fecundos métodos de trabalho, energias ignoradas, europeu mediano não suspeita. ${ }^{24}$

Isso porque os europeus somente conheciam verdadeiramente da China a orla marítima e os seus portos comerciais, onde fervilhavam homens

\footnotetext{
${ }^{22}$ QUEIRÓS, s/d., p. 1258. (grifos nossos).

${ }^{23}$ QUEIRÓS, s/d., p. 1257. (grifo nosso).

${ }^{24}$ QUEIRÓS, s/d., p. 1259.
} 
iletrados, grosseiros, maltrapilhos, carregadores, vendedores ambulantes; poucos estrangeiros teriam se aventurado pelo interior do país, de forma que não se podia avaliar toda a sociedade chinesa por essa baixa matula. Nesse exercício de alteridade, por meio do qual o autor de Os Maias reavalia o imaginário construído em torno de chineses, coreano e japoneses, temos uma reflexão de mão dupla, pois, na condição de um europeu, Eça cria esse Nós irônico que descontrói a visão estereotipada sobre o oriental. Por outro lado, o sujeito discursivo fala também do ponto de vista do "outro", como o chinês olha para o ocidente e como caracteriza a raça e a cultura do branco europeu. Assim,

O Chinês tem pelo Europeu um horror, de instinto e de razão, fisiológico e raciocinado (...) Estes homens (diz essa amarga narração) pertencem a uma raça selvática que habita regiões escuras e húmidas, e que nunca teve a vantagem de se relacionar e aprender com a China. São criaturas avermelhadas, de olhos azulados e estúpidos, e imensos pés de mais de um côvado. Parecem lamentavelmente ignorantes. E como aspecto exterior nada se pode imaginar de mais exótico e repelente! ${ }^{25}$

Eça reconstrói em seu artigo o contexto histórico da guerra entre Japão e China pela posse da Coréia. Desse embate, saíram vitoriosos os japoneses, os quais impulsionaram, indiretamente, os chineses para a imigração, em busca de conhecimentos científicos, industriais e bélicos na Europa, pois foi com essa estratégia que a nação inimiga sobressaiu sobre eles. $\mathrm{O}$ escritor português aponta a modernização da China e a sua europeização - igualando-se em potência e poder bélico ao Japão: "Ora quando a China se tornar militar, extremamente poderosa, a Europa ficará numa situação singularmente perigosa." ${ }^{26}$. Mas o que o Ocidente deve temer não é uma guerra armada da China, considerada por Eça uma pátria de raça de lavradores governada por uma classe de literatos. Segundo o autor português, os imigrantes chineses que foram para Califórnia eram provenientes de uma classe rural remediada, possuíam instrução média e pecúlio.

A discussão de Eça, em muitos aspectos se assemelha aos discursos de Joaquim Nabuco. Ao referir-se à imigração dos chineses para Hava-

\footnotetext{
${ }^{25}$ QUEIRÓS, s/d. p. 1262.

${ }^{26}$ QUEIRÓS, s/d., p.1267.
} 
na, situação que o cônsul de Havana na época conheceu tão de perto, ele afirma que "em serviço onde todas as raças sucumbem, mesmo a negra, o chinês prospera, fica mais luzidio e gordo." ${ }^{27}$. Outro aspecto mencionado é que o chim trabalha pela metade do preço e junta economias quando nenhum outro trabalhador o conseguiria fazer, o que acarretou, de fato, um conflito de raças. Ao final do seu artigo, Eça se dirige aos brasileiros da seguinte forma:

Vós, amigos, aí no Brasil, parece que os desejais, para vos plantar e vos colher o café. Sereis inundados, submergidos. Virão cem, virão logo cem mil. Daqui a dez anos em São Paulo e no Rio tereis vastos bairros chineses, com tabuletas sarapintadas de vermelho e negro, fios de lanternas de papel, covis empestados de ópio, toda a sorte de associações secretas, uma força imensa crescendo na sombra, e cabaias e rabichos sem cessar fervilhando. ${ }^{28}$

Em nenhum momento do seu texto Eça demonstra preocupação com a mestiçagem oriental. Para ele, não há um perigo de caráter racial e, sim, de ordem econômica. O chinês é um trabalhador resistente, que se contenta com baixos salários e toma o trabalho do europeu. Ironicamente, Eça de Queirós afirma que o chim, depois de juntar alguma economia, ainda volta para a China, levando o dinheiro do branco. Como se vê e é justificável, pois o contexto histórico e social do português é bem diferente do vivido por Joaquim Nabuco, não há no artigo eciano a reflexão de que a imigração chinesa afastaria o imigrante alemão ou italiano, já mencionado anteriormente. Acentuando ainda mais o tom jocoso, dialógico com o leitor do "Gazeta de Notícias", Eça finaliza os seus apontamentos com a afirmação de que o chinesismo não será para o Brasil senão um ligeiro acréscimo de confusão - em trocadilho com confucionismo -, sugerido como leitura e aprendizagem para os brasileiros, para estabelecer, aqui, princípios salutares da disciplina, do respeito, da tolerância, da ordem e da paz laboriosa.

\footnotetext{
${ }^{27}$ QUEIRÓS, s.d., p.1268.

${ }^{28}$ QUEIRÓS, s.d., p,1270.
} 


\section{Machado de Assis - a Imigração chinesa sob as lentes de um bruxo}

A imigração chinesa foi abordada em cinco crônicas escritas por Machado de Assis para o Jornal "Gazeta de Notícias". A primeira, de 14 de agosto de 1892, inicia-se com a afirmação de que a semana se resumiu em finanças. No entanto, o cronista não se julga competente o suficiente para comentar esse assunto, pois não possui a ciência do imposto, a lei do câmbio, e mal distingue dez mil-réis de dez tostões. Ademais, "há sempre três e quatro pessoas (principalmente agora) que tratam das coisas financeiras e econômicas, e das causas das cousas, com tal ardor e autoridade, que me oprimem." ${ }^{29}$. Logo, Machado abandona a reflexão sobre a economia brasileira e desvia o seu olhar, focalizando suas lentes em uma tabuleta que havia lido a inscrição "Ao Planeta do Destino", título intencionalmente obscuro. Detido em analisar tal título, o autor de D. Casmurro inverte-o, encontrando nele mais senso. Assim, segundo ele, parece ser a ciência econômica e financeira do nosso país.

Aparentemente, essa referência oferecia pouco sentido para o leitor de seu tempo, ainda mais para o leitor de hoje; no entanto, as citações e analogias nos textos machadianos trazem sempre uma segunda intenção, na superfície, obscura. Veremos como articular as primeiras informações dessa crônica com o tema que nos interessa mais neste estudo. Desviando-se do enfoque econômico, Machado diz que "O senado discutiu o chim, o arroz, o chá, e naturalmente tratou da raça chinesa, que uns defendem e outros atacam. Eu não tenho opinião; mas nunca ouso falar de raças, que me não lembre do Honório Bicalho." ${ }^{30}$. Nessa fala, fica claro que a imigração chinesa trazia dois problemas, um de ordem econômica e outro, de caráter racial. Por outro lado, devemos duvidar da afirmação de que Machado não tivesse opinião sobre a imigração e sobre o cruzamento racial. A seguir, o cronista relata que Honório Bicalho, em visita ao Rio Grande do Sul, tentou colher uma flor na entrada da cidade, mas, não conseguindo, pediu ajuda a um moleque, que vinha da povoação, o qual não compreendeu a sua solicitação, pois falava apenas alemão, o que conduziu Bicalho à seguinte reflexão: "Achei-me estrangeiro no meu próprio país!"

Habilmente ambíguo e lacônico em sua forma de construir a crônica, Machado de Assis acrescenta um terceiro assunto, relacionado à tentativa

\footnotetext{
${ }^{29}$ ASSIS, 1961, p. 97. Vol. 26.

${ }^{30}$ ASSIS, 1961, p. 97. Vol. 26.
} 
frustrada de canonizar Colombo, devido à descoberta de seus amores com uma judia. Juntando as peças dispersas, podemos encontrar um sentido para o título da tabuleta, se o invertermos, como propôs o cronista, ao iniciar o seu texto. Teremos, então, "O destino do Planeta"; por conseguinte, o "ser estrangeiro no próprio país" prenuncia a ocupação chinesa no Brasil, que desencadeará o conflito de raças e o surgimento do prenconceito e do medo do asiático. No entanto, Machado não diz, mas... sugere! A crônica finaliza com uma irônica intertextualidade bíblica, na qual os cânticos dos cânticos, de Salomão, são invocados, para, por meio de uma paródica poesia, dar um pouco de sentido à influência erótica que a judia exercera sobre Colombo, a tal ponto de fazê-lo perder a canonização póstuma.

Como já foi apontado por vários estudiosos da obra machadiana, entre eles Lúcia Granja, Lúcia Miguel Pereira e Brito Broca, a crônica serviu de laboratório para que Machado desenvolvesse algumas técnicas de construção ficcional, como o dialogismo com o leitor, as constantes intertextualidades com a história e personagens da época, e as citações invertidas ou "fingidas", o cronista retoma o tema da imigração chinesa em crônica do dia 11 de setembro de 1892, iniciando-a com a teoria das idéias grávidas, já referida em outros textos que o seu leitor do "Gazeta" havia lido: "O Chaucer vinha entrando a nossa barra, quando da fortaleza de Santa Cruz lhe fizeram alguns sinais, a que ele não atendeu e veio entrando. A fortaleza disparou um tiro de pólvora seca, ele veio entrando; depois outro, ele ainda veio entrando. Quando vinha já entrando de uma vez, a fortaleza soltou a bala do estilo, que lhe furou o costado". Machado aproveita o incidente para fazer referência ao poeta inglês Geoffrey Chaucer, autor dos Contos da Cantuária. A tese machadiana firma-se na hipótese de que ação puxa ação, idéia puxa idéia, desdém chama desdém, assim, "Um homem a quem se puxa o nariz, acaba recebendo um rabo de papel" ${ }^{1}$. E o cronista nos daria mais exemplos, mas, se o leitor não entende a sua teoria com um, não a entenderá com três.

$\mathrm{O}$ que Machado queria informar ao leitor, por meio dos seus jogos ficcionais, é que a semana teve uma grossa emissão bancária: debêntures e mais debêntures - um excesso financeiro provocado por um simples papel -, um bilhete de crédito. As idéias grávidas serão encampadas por uma associação com a conjuração mineira, a partir da "simples" expressão "Amanhã é o batizado", também veiculada à maneira das emissões de crédi-

${ }^{31}$ ASSIS, 1961, p. 117. Vol. 26. 
to - um bilhete. O cronista dá adeus ao leitor, mas não abandona a escrita do seu texto, estende o seu adeus aos chins,

porque é possível que eles venham, como que não venham. O Diário de Notícias, contando os votos da câmara prováveis e desfavoráveis, dá 64 para cada lado. Numa questão intricada era o que melhor podia acontecer; as opiniões entestavam umas com outras, na ponte, como as cabras da fábula. Mas pode haver alterações, e há de havê-las. Para isso mesmo é que se discute. E a balança está posta em tal maneira, que a menor palha fará pender uma das conchas. ${ }^{32}$

Com essa reflexão, Machado de Assis analisa como estava a discussão no senado sobre a autorização para a imigração chinesa e informa ao seu leitor como as opiniões estavam tão divididas e equilibradas sobre uma questão intricada e polêmica. $\mathrm{O}$ empate na votação lembra a responsabilidade de um brasileiro quanto a sua opinião; segundo o cronista, o futuro do Brasil "ou há de ser próspero com os chins, conforme opinam uns, ou desgraçado, como querem outros." ${ }^{33}$. Enfim, a crônica finaliza sem que o seu autor acrescente mais detalhes para essa polêmica.

No dia 18 de setembro de 1892, Machado de Assis retoma a discussão sobre a imigração chinesa de forma mais direta. Já no primeiro parágrafo, o assunto é referido: Quando a China souber que a vinda dos seus naturais (votada esta semana em segunda discussão), tem dado lugar a tanto barulho, tanta animosidade, tanto epíteto feio, é provável que mande fechar os seus portos e não deixe ninguém sair". Ironicamente, o cronista acrescenta que "conhece a China", que a China tem brios. Nessa crônica, Machado de Assis chega ao ponto de comparar o imigrante asiático com os imigrantes europeus, apontando as vantagens dos primeiros:

Força é confessar que os filhos daquelas bandas têm grandes vantagens. Italianos entram aqui com o seu irridentismo, franceses com os princípios de 89, ingleses com o Foreign Office e a câmara dos comuns, espanhóis com todas las

\footnotetext{
${ }^{32}$ ASSIS, 1961, p. 120. Vol. 26.

${ }^{33}$ ASSIS, 1961, p.120. Vol. 26.
} 
Espãnas, caramba! Alemães com uma casa sua, uma cidade sua, uma vida sua. Chim não traz nada disso, traz braço, força e paciência. ${ }^{34}$

Ainda que ironize até mesmo os nomes dos chineses, impronunciáveis, comparados com espirros, Machado afirma que o chinês é um trabalhador assíduo e incansável. Segundo ele, por informação do padre João de Lucena, na China até os cegos e aleijados desenvolvem algum tipo de trabalho. E exorta ao leitor: "Não alegueis serem estas notícias de um velho escritor, porque uma das vantagens da China é ser a mesma." ${ }^{35}$. O cronista, como de costume, desvia seu olhar para outro assunto, a proposta de se erguer um monumento em homenagem ao imperador do Brasil, na época do término da Guerra do Paraguai e a recente contribuição que Machado receberia de Jules Simon, ex-ministro, senador e pensador, cuja carta, em francês, é transcrita para a crônica, como recurso dialógico e ficcionalizante.

No dia 25 de setembro de 1892, Machado de Assis começa a crônica informando que a semana começou mal. Segundo ele, as últimas informações sobre a imigração chinesa foram interpretadas pelos leitores como uma defesa em favor do chim, conforme as vinte e seis cartas recebidas, a que o cronista retruca:

Eu não sou homem que recuse elogios. Amo-os; eles fazem bem à alma e até ao corpo. As melhores digestões da minha vida são as dos jantares em que sou brindado. Mas confesso que desta vez nem tive tempo de saborear os louvores; fiquei espantado, porque eu não defendi nada, nem ninguém. Não fiz mais que apontar as qualidades dos chim e as de outros imigrantes, para significar que, entrado o chim, os outros somem-se. Não defendi, nem acusei. Não me deitem louros nem grilhões. ${ }^{36}$

O discurso machadiano instaura no leitor uma angústia de sentido, de incompreensão do dito, ou de conflito na tentativa de captar o que pensava o autor de Esaú e Jacó sobre essa questão. O que procuramos demonstrar em nossa análise é exatamente que esse autor manifestava, sim, sua opinião sobre a imigração chinesa, por meio de declarações truncadas, escamoteadas

\footnotetext{
${ }^{34}$ ASSIS, 1961, p. 123. Vol. 26.

${ }^{35}$ ASSIS, 1961, p. 124. Vol. 26.

${ }^{36}$ ASSIS, 1961, p. 128. Vol. 26.
} 
por outras referências nem sempre diretas para o leitor. Nessa passagem mesmo, Machado diz que não defendeu o chim, e acrescenta outra afirmação: quando os chins chegarem ao Brasil, sumirão os outros imigrantes. Essa declaração dialoga bem com os discursos de Joaquim Nabuco, quando defendia que os asiáticos seriam impecilho para a entrada e a permanência de imigrantes brancos europeus, idéia também presente do artigo de Eça de Queirós. Assim, pelo viés do não-dito, diz-se que o chim não é desejado porque será obstáculo para outros imigrantes “ideais". Essa interpretação pode ser balizada no discurso do próprio Machado, quando, ainda nessa crônica, avisa ao leitor: "Se não são estas as textuais palavras, advirtam que foram transcritas por mim, cujo falar ou escrever tem o vício de ser torto, truncado ou brusco; mas o sentido aí está. Fique o sentido e vamos ao arroz." ${ }^{37}$. Nessa crônica, a opinião contrária de Machado de Assis quanto à imigração chinesa parece mais evidente, pois o autor desdobra o seu pensamento, vaticinando o que acontecerá ao Brasil em 1914, quando vierem as maldições ou as bênçãos. No entanto, os que estiverem enterrados, não se importarão com elas, pois os mortos, se não falam, também não ouvem: "Também não se nos dará de agitações sociais ou outros desconsolos; menos ainda se o Império do Meio fizer da nossa terra uma República do Meio. Teremos vivido."38. Como se vê, Machado prevê agitações sociais, desconsolos e um sentimento nacional de perda, quando o Brasil se tornar uma China Americana. Teremos sobrevivido? O cronista abandona a reflexão e volta a informar ao leitor que o dinheiro arrecadado para erguer a estátua em homenagem ao Imperador foi destinado à construção de um belo edifício, doado ao governo e ocupado por duas escolas.

No dia 28 de maio de 1894, Machado de Assis voltará a escrever sobre a imigração asiática, com ênfase na visita a São Paulo de Sho Nemotre, um comissário japonês encarregado de estudar as condições de vida dos imigrantes japoneses nas fazendas brasileiras. Nessa crônica, já não há mais o tom de polêmica, pois, entre os anos de 1892 e 94, já haviam chegado grupos de chineses para a plantação de chá. A crônica também faz referências à guerra travada entre Japão e China pela posse da Coréia, conforme discutimos no artigo de Eça de Queirós. Ainda que não haja um tom de polêmica nesse texto, Machado não deixa de brincar com a situação do

\footnotetext{
${ }^{37}$ ASSIS, 1961, p. 129. Vol. 26.

${ }^{38}$ ASSIS, 1961, p.129. Vol. 26.
} 
asiático no Brasil. Para esse autor, o chim tem os seus poucos méritos; o maior deles é chá, "merecimento grande, que vale ainda mais que a filosofia e a porcelana." ${ }^{39}$. Ele mesmo teria visto no Rio de Janeiro alguns chineses, que lhe pareceram alegres, da boca do intérprete, é verdade, mas que nos importa a alegria ou a tristeza dos chins? Entreabre um sorriso ao canto da boca o maldoso bruxo do Cosme.

Por fim, Machado escreverá ainda uma última crônica para o "Gazeta de Notícias" sobre esse assunto no dia 18 de outubro de 1896. Significativamente, a crônica se abre com a informação de que a febre amarela volta a ameaçar o saneamento do Rio de Janeiro. Quase todo o texto é dedicado a comentar o novo surto da temível doença. Para acrescentar dados as suas informações, o cronista afirma que os italianos não crêem nesse mal, assim como os portugueses, alemães, franceses, russos, belgas, ingleses e outros. "Quem crê deveras na febre é o chim; no ano passado não entrou nenhum, dizem as estatísticas; mas por que notam elas esta ausência do chim, e não citam a do abexim? Eis aí um mistério, que não será o primeiro nem o último das estatísticas." ${ }^{40}$. Interessante como, nessa crônica, Machado nos transmite a imagem do Brasil como um país de muitas raças, uma verdadeira babilônia tropical, que receberá, também, a influência cultural dessas nações. Para tal propósito, o cronista relata a morte e o funeral do grande compositor e maestro Carlos Gomes e relaciona com a chegada de barítonos italianos junto às levas de agricultores italianos. Segundo Machado, nem só de café vive o homem, mas também da palavra de Verdi e de Carlos Gomes.

Com o estudo dessas crônicas, percebemos que a imigração asiática foi inevitável, guardadas suas proporções e efeitos sobre a nossa raça e cultura. Inicialmente, considerada como uma terrível doença, uma verdadeira febre amarela, mas que foi suavizada pela presença de outros imigrantes que abraçaram essa terra como suas pátrias do exílio e que continuam entre nós, sem a tão temida ameaça oitocentista de nos fazermos sentir estrangeiros no nosso próprio país. A referência da música italiana no Brasil e a valorização de Carlos Gomes na Itália representaram para Machado de Assis a possibilidade dos diálogos culturais, assim como, para nós, participantes desse XXI congresso brasileiro de professores de Literatura Portuguesa, hoje, a realidade dessas felizes relações transatlânticas.

\footnotetext{
${ }^{39}$ ASSIS, 1961, p. 212. Vol. 27.

${ }^{40}$ ASSIS, 1961, p. 306. Vol. 28.
} 


\section{Referências Bibliográficas}

AZEVEDO, Célia Maria Marinho de. Onda negra, medo branco: o negro no imaginário das elites do século XIX. São Paulo: Annablume, 2004.

BOSI, Alfredo. "O teatro político nas crônicas de Machado de Assis". In Brás Cubas em três versões - estudos machadianos. São Paulo: Companhia das Letras, 2006.

BROCA, Brito. Machado de Assis e a política e outros estudos. São Paulo: Polis, 1983.

COSTA, Emília Viotti da. Da Monarquia à República: Momentos decisivos. São Paulo: UNESP, 1999.

FAORO, Raymundo. Machado de Assis: a pirâmide e o trapézio. Rio de Janeiro: Globo, 1988.

GLEDSON, John. Machado de Assis - ficção e história. Rio de Janeiro: Paz \& Terra, 2003.

JOBIM, José Luís. "Quem deve ser brasileiro? As opiniões de Taunay e Machado de Assis sobre a nacionalização". In Matraga - Revista do programa de pós-graduação em Letras da UERJ. V.17. Rio de Janeiro: Editora Caetés, 2005, p. 13-23.

MAGALHÃES JR, Raimundo. Machado desconhecido. Rio de Janeiro: Civilização Brasileira, 1955.

NABUCO, Joaquim. Discursos parlamentares. Rio de Janeiro: Imprensa Nacional, 1950.

SCHWARZ, Roberto. Um mestre na periferia do capitalismo: Machado de Assis. São Paulo: Duas Cidades, 1991.

SKIDMORE, Thomas E. Preto no branco: raça e nacionalidade no pensamento brasileiro. Rio de Janeiro: Paz e Terra, 1989. 